\title{
Medium and large sized mammals of a semideciduous forest remnant in southern Brazil
}

\author{
Daniel Paulo de Souza Pires ${ }^{1,3}$ \& Cristina Vargas Cademartori ${ }^{2}$ \\ ${ }^{1}$ Programa de Pós-graduação em Biologia Animal, Departamento de Zoologia, Instituto de Biociências, \\ Universidade Federal do Rio Grande do Sul - UFRGS, Av. Bento Gonçalves, 9500, Prédio 43435, \\ CEP 91540-000, Porto Alegre, RS, Brasil. http://www.ufrgs.br/zoologia/ppgban \\ ${ }^{2}$ Laboratório de Manejo de Fauna, Pós-graduação e Pesquisa, Centro Universitário La Salle - Unilasalle, \\ Av. Victor Barreto, 2288, CEP 92010-000, Canoas, RS, Brasil. http://unilasalle.edu.br/canoas/mestrado \\ ${ }^{3}$ Corresponding author: Daniel Paulo de Souza Pires, e-mail: pires.daniel@yahoo.com.br
}

PIRES, D.P.S. \& CADEMARTORI, C.V. Medium and large sized mammals of a semideciduous forest remnant in southern Brazil. Biota Neotrop. 12(3): http://www.biotaneotropica.org.br/v12n3/en/abstract?inv entory+bn01412032012

\begin{abstract}
Knowledge about mammals of the Atlantic Forest is still lacking, especially because some places remain poorly studied or inventoried, which makes conservation initiatives difficult. We aimed to determine the species richness and composition of medium and large sized mammals in a semideciduous forest remnant, Morro do Coco, thus contributing information about the occurrence of mammalian fauna in the metropolitan region of Porto Alegre, southern Brazil. The methods consisted of interviews with local inhabitants, visual records and sand plot analysis. The study took place from July 2008 to April 2009, with monthly expeditions of three days. Sixteen species of mammals were recorded, seven of which are threatened with extinction in Rio Grande do Sul and one nationally. The predominant trophic group was the frugivorous/herbivorous. The study area is situated in a prioritized zone for the conservation of mammals in Greater Porto Alegre, since it consists of one of the last remnants where the phytophysionomies that originally occupied the edge of Guaiba Lake and granite hills of the region are represented and preserved.
\end{abstract}

Keywords: mammalian fauna, tracks, Atlantic Forest Domain, sand plots, visual records.

PIRES, D.P.S. \& CADEMARTORI, C.V. Mamíferos de médio e grande porte de um remanescente de Floresta Estacional Semidecidual no sul do Brasil. Biota Neotrop. 12(3): http://www.biotaneotropica.org.br/v12n3/pt/ abstract?inventory+bn01412032012

Resumo: O conhecimento sobre a mastofauna da Mata Atlântica é ainda insuficiente, especialmente porque restam locais pouco estudados ou mal inventariados, o que dificulta iniciativas de conservação. Teve-se, como objetivos, conhecer a riqueza e a composição de espécies de mamíferos de médio e grande porte em um remanescente de Floresta Estacional Semidecidual, o Morro do Coco, contribuindo, assim, com informações sobre a ocorrência da mastofauna na região metropolitana de Porto Alegre, sul do Brasil. A metodologia consistiu de entrevistas com moradores locais, registros visuais e parcelas de areia. O estudo transcorreu de julho de 2008 a abril de 2009, com expedições mensais de três dias. Foram registradas 16 espécies de mamíferos, sete das quais estão ameaçadas de extinção no Rio Grande do Sul e uma nacionalmente. O grupo trófico predominante foi o de frugívoros/herbívoros. A área de estudo situa-se em uma zona prioritária à conservação da mastofauna na Grande Porto Alegre, por ser um dos últimos remanescentes onde estão representadas e preservadas as fitofisionomias que originalmente ocupavam a orla do Lago Guaíba e os morros graníticos da região.

Palavras-chave: mastofauna, pegadas, Domínio da Mata Atlântica, parcelas de areia, registros visuais. 


\section{Introduction}

The search for conservationist actions has led scientists throughout the world to understand and discuss the main environmental impacts of the unbridled actions of humanity, and also to find ways of confronting and reducing the loss of biodiversity. One of the principal impacts of anthropic activities on biodiversity is the loss and reduction of habitats, which contributes to the extinction of species of the world's fauna (Primack \& Rodrigues 2001).

The conservation of an ecosystem and its utilization in a sustainable manner depends on fauna inventories (Primack \& Rodrigues 2001, Pardini et al. 2003, Rocha \& Dalponte 2006). Information on abundance and distribution are very important to evaluate the state of conservation of a taxa (Butchart et al. 2006), and one of the difficulties in this evaluation, at the national level, is the scarcity of published data on the composition and abundance of species at local and regional levels (Machado et al. 2008).

The Atlantic Forest was the biome most affected by the settling of Brazil (Tabarelli et al. 2005, Tonhasca Junior 2005, Lagos \& Muller 2007). Still, it is believed that the region encompasses $8 \%$ of the world's biodiversity and a large number of endemic species (Lagos \& Muller 2007), sustaining 261 species of mammals, $61 \%$ of which are endemic (Costa 2001, Lagos \& Muller 2007). However, knowledge of the fauna of this biome is still lacking, including the areas close to big cities, where it is not uncommon that there are animals essential to the maintenance of the ecological systems, such as medium and large sized mammals (Tonhasca Junior 2005, Penter et al. 2008, Abreu Junior \& Köhler 2009).

The mammals are a representative group of the tropical fauna (Costa 2001). Mammalian species respond differently to alterations in their habitats, where some communities are more sensitive than others to environmental perturbations over time. Mammals are especially affected by the loss and alteration of habitats, since they are important components of terrestrial ecosystems, whether in terms of biomass, trophic interactions or their essential role in the maintenance and regeneration of tropical forests through the dispersal of seeds and predation of seedlings (Redford \& Eisenberg 1992, Silva 1994, Tonhasca Junior 2005, Carvalho Junior \& Luz 2008).

The fauna of mammals in Rio Grande do Sul comprises 166 species already recorded (Fontana et al. 2003). This total accounts for almost $25 \%$ of the 701 species mentioned by Paglia et al. (2012) for Brazil. However, many ecological and biological aspects of medium and large sized mammals are still little known, due to the difficulties in their observation and study (Silva 1994, Pardini et al. 2003).

The metropolitan region of Porto Alegre is made up of a vegetational mosaic composed of fields and forests, predominant especially in the hills, which results from the combination of geomorphological diversity and transitional climatic conditions, because it is situated between temperate and tropical regions (Menegat et al. 1998). Such conditions, although having revealed a high richness and diversity of species for other faunistic groups (Lema et al. 1983, Scherer et al. 2006, Santos \& Cademartori 2010), have been little explored with respect to the mammalian fauna. The species richness of mammals has been insufficiently studied in the forest remnants of the region (Antonio 1996, Sestren-Bastos 2006, Penter et al. 2008), where there is a need for information from more long-term inventories.

Therefore, with the aim of contributing to the conservation and maintenance of the constituent natural processes of forest remnants in the state of Rio Grande do Sul, we studied the species richness and composition of mammals of medium and large size in Morro do Coco and also updated the information on the occurrence of the mammalian fauna in the metropolitan region of Porto Alegre.

\section{Materials and Methods}

The study area is situated in Morro do Coco, a remnant of a seasonal semideciduous forest of about 142 ha that belongs to the Atlantic Forest Domain (Figure 1). It is located in the municipality of Viamão, state of Rio Grande do Sul, between $30^{\circ} 16^{\prime} 15^{\prime \prime} \mathrm{S}$ and $51^{\circ}$ 02 ' 54 ' W, $50 \mathrm{~km}$ to the south of Porto Alegre and about $15 \mathrm{~km}$ from the lighthouse of Itapuã (Menegat et al. 1998). It has an elongated shape, east to west, where the eastern point projects into Guaíba Lake (Backes 2000). It is situated in a matrix with a predominance of rural activity, with substantial farming, intertwined with urban centers. The landscape consists of isolated hills and low lands that extend up to Guaíba Lake, whose banks are broken up by points and coves (Hickel et al. 1998). In this region, there are still patches of vegetation that interconnect important forest remnants such as Morro São Pedro, Morro da Extrema, Morro do Coco and Parque Estadual de Itapuã, among others (Figure 1).

The climatic and edaphic factors have a strong influence on the vegetation of this area, determined by the occurrence of a clean field, dirty field, shrub field, forest fragments and continuous forest (Backes 2000). The forest of Morro do Coco is not continuous in all directions. According to Knob (1978), the vegetation of the hills of Greater Porto Alegre has already been almost totally destroyed or modified, but the vegetation of Morro do Coco is in an advanced stage of ecological succession.

The climate in the region is of the Cfa type, according to the Koeppen classification, that is, subtropical climate with dominant influence of the territorial configuration (C), with cool winters (f) and a minimal temperature of $3{ }^{\circ} \mathrm{C}$ recorded in June and July. The summer is hot, with a maximal absolute temperature of $41^{\circ} \mathrm{C}$ recorded in December, and mean of the warmest month higher than $22^{\circ} \mathrm{C}$ (a).

Samplings were carried out monthly in a period of 10 months, from July 2008 to April 2009.The time spent in the area at each expedition was three days, totaling a period of 30 days of field activities.

In this study, the mammals considered were of medium and large size, with a body weight over $1 \mathrm{~kg}$ when adults (Chiarello 2000).

For the screening of tracks, 20 sand plots were placed in two transects, each at a distance of $20 \mathrm{~m}$ from the other, 10 on the edge of and the other 10 inside the forest. The sand plots consisted of wooden frames with a size of $50 \mathrm{~cm}$ in length $\times 50 \mathrm{~cm}$ in width $\times 5 \mathrm{~cm}$ in height, without bottom. The plots were examined daily, moistened with a sprinkler, leveled and the bait was replaced when it was taken. The choice of baits for the herbivorous animals (banana) and for the carnivorous animals (bacon) was according to Pardini et al. (2003). To increase the probability of capturing different species in the areas sampled, the types of bait utilized were switched with each expedition. Therefore, bacon was used in one transect and banana in the other, reversing the type of bait in transects every month. The sampling sites were studied simultaneously, with the same effort for both, totaling 300 plots for each transect $\left(75 \mathrm{~m}^{2}\right.$.day per transect).

Besides the use of sand plots placed in the two transects already described, screening of tracks on the lake bank was carried out by excursions on foot during the day and eventually at night. The effort allotted was two hours per day, totaling 60 hours.

Besides the tracks, the occurrence of the mammals was determined by sightings. The sightings were recorded while covering trails and transects in the study area. Daily walks of about two hours were taken, totaling an effort of 60 hours. The recordings obtained in 120 hours of effort, including tracks and visual, were counted per day, that is, species per day, taking into account a single daily recording per species. The tracks were identified based on the previous experience of the observer, using field guides (Becker \& Dalponte 


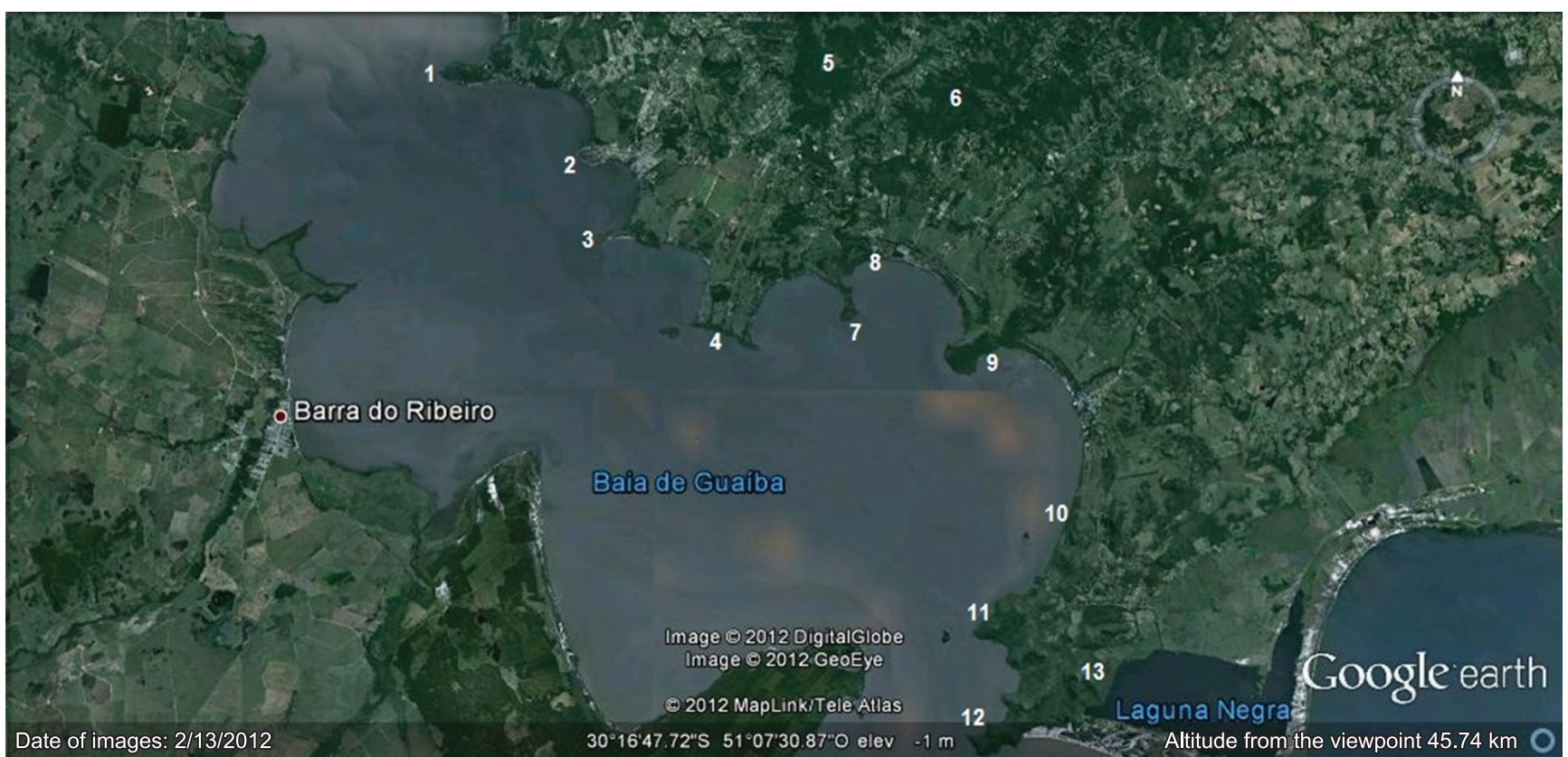

Figure 1. Location of the study area and main hills and patches of forest that compose the landscape on the edge of Guaíba Lake (Google Earth 2012). 1. Ponta Grossa, 2. Ponta da Cuíca, 3. Ponta do Arado, 4. Ponta das Canoas, 5. Morro São Pedro, 6. Morro da Extrema, 7. Ponta do Cego, 8. Reserva Biológica do Lami José Lutzenberger, 9. Morro do Coco, 10. Parque Estadual de Itapuã, 11. Morro da Fortaleza, 12. Ponta de Itapuã, 13. Morro da Grota.

1991, Borges \& Tomaz 2008, Carvalho Junior \& Luz 2008) and by consulting specialists. Ten local inhabitants were interviewed with the aim of confirming and complementing the visual and track recordings, utilizing a questionnaire adapted from Santos (2001). Recordings were considered valid only if confirmed by at least two inhabitants in a period of five years, accompanied by a detailed description, followed by the identification of the animal from a photograph.

The species accumulation curve was obtained based on the number of species recorded per month. The program EstimateS 8.5 was used to estimate the species richness of the study area, and the results were submitted to the estimators Chao 1, Jacknife 1 and Bootstrap. The first estimator is based on abundance and considers exclusively the species with a low number of recordings, while the second is based on incidence and considers only rare species, found in only one or two samples; the third estimates total richness, using data of all species, not just rare species (Colwell 2009).

The occurrence constancy of the species was evaluated by the index developed by Silveira-Neto et al. (1976), based on the scale proposed by Santos et al. (2008): species encountered in more than $50 \%$ of the samplings are considered constant, those present between 25 and $50 \%$ are accessory, and those with a level less than $25 \%$ are considered occasional. For constancy analysis, only sand plots and visual recordings were considered. Each species was assigned to a trophic category according to Paglia et al. (2012) and the degree of threat followed Fontana et al. (2003) and Machado et al. (2008).

\section{Results}

In the period of ten months, 16 species of mammals were recorded in Morro do Coco, distributed into 15 families and eight orders (Table 1), including the exotic species Lepus europaeus Pallas, 1778. The estimator of species richness Jacknife 1 determined 17 species for the locality, while the estimators Chao 1 and Bootstrap estimated 16 species (Figure 2). Seven of the 16 species detected are threatened with extinction in Rio Grande do Sul, all included in the category Vulnerable (Table 1).
The method that was the most efficient for the detection of the mammalian fauna of medium and large size was that of trails (14 species), followed by interviews (13 species) and sightings (6 species).

Considering the total recordings, the most frequent species in Morro do Coco was Alouatta guariba Cabrera, 1940, with 31\% of the total, followed by Didelphis albiventris Lund 1840, with 30\%. The other species combined comprised $39 \%$ of the recordings.

An analysis of the trophic categories revealed that six species $(37.5 \%)$ are herbivorous, six $(37.5 \%)$ are omnivorous, three $(19 \%)$ are carnivorous or piscivorous and one $(6 \%)$ is myrmecophagous (Table 1). The constancy index revealed that two species were accessory in the area and 13 occasional (Table 1).

\section{Discussion}

Based on the similar results of the three estimators of species richness used, the locality was well sampled. However, according to Santos (2003), the majority of the methods utilized for estimating species richness generally underestimate the richness of the community, because it is very difficult if not impossible to assess how close estimations are to the true richness of the community. According to this author, the suitability of these methods for studies of biological diversity is still poorly known, and their application in ecology is relatively recent, which requires caution in the interpretation of the results. Considering that the surrounding region has been little studied and that the period of study was not of long duration, new species can probably be recorded in Morro do Coco and surroundings. Felines of the genus Leopardus and cervids of the genus Mazama, for example, often appear in reports by inhabitants around the study area (D.P.S. Pires, personal observation), suggesting that new species could be recorded. Knowing that the detection of all species of an area is practically unattainable, especially in complex ecosystems, and that the species accumulation curve did not reach a plateau, it cannot be stated that Morro do Coco is completely inventoried.

Species richness in Morro do Coco differs more or less from that of the surrounding regions and of the other hills of Porto Alegre. The 
Pires, D.P.S. \& Cademartori, C.V.

Table 1. Medium and large sized mammals recorded in Morro do Coco, RS, from July 2008 to April 2009.

\begin{tabular}{|c|c|c|c|c|c|}
\hline ORDER/Family/Species & Trophic category & $\mathbf{n}$ & CI & $\begin{array}{c}\text { Form of } \\
\text { recording }\end{array}$ & $\begin{array}{c}\text { Conservation } \\
\text { status }\end{array}$ \\
\hline \multicolumn{6}{|l|}{ DIDELPHIMORPHIA } \\
\hline \multicolumn{6}{|l|}{ Didelphidae } \\
\hline Didelphis albiventris (Lund, 1840) & Frugivorous/Omnivorous & 30 & A & $\mathrm{T}, \mathrm{I}$ & NT \\
\hline \multicolumn{6}{|l|}{ PILOSA } \\
\hline \multicolumn{6}{|l|}{ Myrmecophagidae } \\
\hline Tamandua tetradactyla (Linnaeus, 1758) & Myrmecophagous & 1 & $\mathrm{O}$ & $\mathrm{T}, \mathrm{I}$ & $\mathrm{V}$ \\
\hline \multicolumn{6}{|l|}{ CINGULATA } \\
\hline \multicolumn{6}{|l|}{ Dasypodidae } \\
\hline Dasypus novemcinctus (Linnaeus, 1758) & Insectivorous/Omnivorous & 2 & $\mathrm{O}$ & $\mathrm{V}, \mathrm{T}, \mathrm{I}$ & NT \\
\hline \multicolumn{6}{|l|}{ PRIMATES } \\
\hline \multicolumn{6}{|l|}{ Atelidae } \\
\hline Alouatta guariba Cabrera, 1940 & Folivorous/Frugivorous & 29 & A & $\mathrm{V}, \mathrm{T}, \mathrm{I}$ & $\mathrm{V}$ \\
\hline \multicolumn{6}{|l|}{ CARNIVORA } \\
\hline \multicolumn{6}{|l|}{ Canidae } \\
\hline Cerdocyon thous (Linnaeus, 1766) & Insectivorous/Omnivorous & 5 & A & $\mathrm{T}, \mathrm{I}$ & NT \\
\hline \multicolumn{6}{|l|}{ Procyonidae } \\
\hline Procyon cancrivorus (G. Cuvier, 1798) & Frugivorous/Omnivorous & 7 & $\mathrm{O}$ & $\mathrm{T}$ & NT \\
\hline \multicolumn{6}{|l|}{ Mephitidae } \\
\hline Conepatus chinga (Molina, 1782) & Insectivorous/Omnivorous & 1 & $\mathrm{O}$ & $\mathrm{T}$ & NT \\
\hline \multicolumn{6}{|l|}{ Mustelidae } \\
\hline Lontra longicaudis (Olfers, 1818) & Piscivorous & 3 & $\mathrm{O}$ & $\mathrm{V}, \mathrm{T}, \mathrm{I}$ & $\mathrm{V}$ \\
\hline \multicolumn{6}{|l|}{ Felidae } \\
\hline $\begin{array}{l}\text { Puma yagouaroundi (E. Geoffroyi) } \\
\text { Saint-Hilaire, 1803) }\end{array}$ & Carnivorous & 1 & $\mathrm{O}$ & $\mathrm{T}, \mathrm{I}$ & $\mathrm{V}$ \\
\hline Leopardus pardalis (Linnaeus, 1758) & Carnivorous & - & - & I & $\mathrm{V}$ \\
\hline \multicolumn{6}{|l|}{ ARTIODACTYLA } \\
\hline \multicolumn{6}{|l|}{ Cervidae } \\
\hline Mazama sp. (Rafinesque, 1817) & Frugivorous/Herbivorous & 2 & $\mathrm{O}$ & $\mathrm{T}, \mathrm{I}$ & $\mathrm{V}$ \\
\hline \multicolumn{6}{|l|}{ RODENTIA } \\
\hline \multicolumn{6}{|l|}{ Erethizontidae } \\
\hline Coendou spinosus (F. Cuvier, 1823) & Frugivorous/Folivorous & 3 & $\mathrm{O}$ & $\mathrm{V}, \mathrm{T}, \mathrm{I}$ & NT \\
\hline \multicolumn{6}{|l|}{ Caviidae } \\
\hline Hydrochoerus hydrochaeris (Linnaeus, 1766) & Herbivorous & 4 & $\mathrm{O}$ & $\mathrm{T}, \mathrm{I}$ & NT \\
\hline \multicolumn{6}{|l|}{ Dasyproctidae } \\
\hline Dasyprocta azarae (Lichtenstein, 1823) & Frugivorous/Granivorous & 1 & $\mathrm{O}$ & $\mathrm{T}$ & $\mathrm{V}$ \\
\hline \multicolumn{6}{|l|}{ Myocastoridae } \\
\hline Myocastor coypus (Molina, 1782) & Frugivorous/Omnivorous & 4 & $\mathrm{O}$ & $\mathrm{V}$ & NT \\
\hline \multicolumn{6}{|l|}{ LAGOMORPHA } \\
\hline \multicolumn{6}{|l|}{ Leporidae } \\
\hline Lepus europaeus (Pallas, 1778) & Herbivorous & 4 & $\mathrm{O}$ & $\mathrm{V}, \mathrm{T}, \mathrm{I}$ & * \\
\hline
\end{tabular}

$\mathrm{n}$ (number of records, considering species per day). CI - Constancy index (A-Accessory, C - Constant, O-Occasional). V-Visual recording, T-Recording by trails, I - Recording by interviews. Conservation status according to Fontana et al. (2003) and Machado et al. (2008): V - Vulnerable, NT - Not threatened, * Exotic species. The trophic categories according to Paglia et al. (2012).

list of species of the Parque Estadual de Itapuã, a conservation unit of approximately 5,500 ha and close to Morro do Coco, consists of 21 species of medium and large sized mammals (Antonio 1996). A survey of mammals carried out by Penter et al. (2008) in Morro Santana, an area of about 1000 ha, noted the presence of 17 species of medium and large sized mammals, a large part being learned through interviews. In fact, only nine of these species were considered with occurrence confirmed by the authors, two of which were not recorded in Morro do Coco, Cavia aperea (Erxleben, 1777) and Cebus nigritus (Goldfuss, 1809). Sestren-Bastos (2006) recorded only four species of mammals of medium and large size in Morro do Osso, in Porto Alegre, one of which was not detected in Morro do Coco, C. aperea, a characteristic species of open formations (Redford \& Eisenberg 1992). The biotic and abiotic characteristics of these hills are similar to those of Morro do Coco; however, Morro Santana and Morro do Osso are much more impacted than Morro do Coco, since the first two are isolated and surrounded by the urban network of Porto Alegre. Parque Estadual de Itapuã, on the contrary, is a more conserved area and far from the urban sprawl, suggesting that the richness of mammals of medium and large size have some relation to the conservation status and degree of isolation of the area. Kasper et al. (2007b), on the other hand, found 28 species in their study in Vale do Taquari. In the Parque Estadual do Turvo, an area of about 17,500 ha, Kasper et al. (2007a) recorded 29 species of mammals of medium and large size. Therefore, there is 


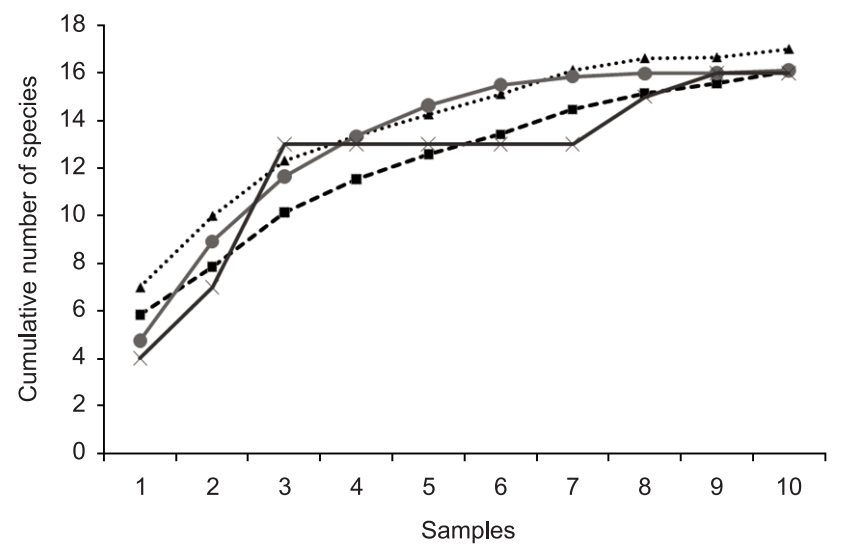

...... Jacknife 1 - --. Chao $1 \multimap$ Bootstrap $\multimap$ Observed

Figure 2. Observed and estimated species accumulation curves for medium and large sized mammals recorded in Morro do Coco, southern Brazil, from July 2008 to April 2009.

a greater difference in species richness in Morro do Coco compared to localities that are much more conserved and continuous, such as Parque Estadual do Turvo, where the number of medium and large sized mammals is much greater.

Although some species have not been recorded in Morro do Coco, their occurrence is expected, especially because they have been detected in nearby areas, such as Parque Estadual de Itapuã and Reserva Biológica do Lami, a conservation unit of 204 ha (Witt 2008). This is the case for C. aperea and Dasypus hybridus (Desmarest, 1804), since there are open formations in the vicinity, and for Galictis cuja (Molina, 1782), capable of occupying forest formations and open areas (Yensen \& Tarifa 2003). It is also the situation for Cabassous tatouay (Desmarest, 1804), recorded by C.V. Cademartori (personal observation) in June 2006 in Lar Nazaré, a social assistance home of approximately 50 ha and about $5 \mathrm{~km}$ from the study area. Cebus nigritus, despite evidence of its presence in granite hills more to the north, in the municipality of Porto Alegre (Gomes 2006, Penter et al. 2008), does not occur in the study area or in Parque Estadual de Itapuã or Reserva Biológica do Lami. This species, easy to detect because of its diurnal habits and conspicuous behavior (Emmons \& Feer 1997), was never mentioned by the interviewees, not even in reference to more remote times. Data on the distribution of C. nigritus, as well as its population densities and use of space are rare in Rio Grande do Sul, and although the species is tolerant to the presence of human and is able to occupy fragmented landscapes, its occurrence and size of groups depend on factors such as dimensions, state of conservation and connectivity between forest fragments, presence of farmland and food offerings by humans (Gonçalves 2006).

In relation to methods used, the combination of the methods was shown to be more effective in detecting the local mammalian fauna than any one of the methods alone. Despite the high number of species obtained with interviews, it should be pointed out that in this case, these were based on only three families, who although living in the area did not venture into the interior of the forest or to areas farther from their homes. Still, the inhabitants had lived in the area for many years and were familiar with the wild fauna, which was accustomed to foraging close to their homes, which guaranteed greater reliability of the reports. Penter et al. (2008) noted that in urban fragments, the interviews can be the best alternative for the recording of species. However, the combined use of various sampling methods appears to be the most efficacious strategy for the detection of a greater number of species (Kasper et al. 2007a).

The high percentage of recordings of $D$. albiventris and $A$. guariba in relation to the other species suggests that both are common in the study area. This result has also been reported by other authors in studies carried out in the region, which indicates that the two species are easily encountered (Antonio 1996, Sestren-Bastos 2006, Penter et al. 2008). It should also be noted that the high percentage of $A$. guariba is due to its diurnal habits and conspicuous behavior, compared to other species of mammals recorded.

With respect to the trophic categories, similar results were obtained by Abreu Junior \& Köhler (2009), who also found a preponderance of omnivorous and frugivorous/herbivorous mammals. The carnivorous and piscivorous groups recorded in Morro do Coco-Puma yagouaroundi (E. Geoffroy, 1803), Leopardus pardalis (Linnaeus, 1758) and Lontra longicaudis (Olfers, 1818) - represent the environmentally more demanding trophic group. Although it is a representative category in Morro do Coco, this does not mean that the area is capable of sustaining these species in the medium and long-term, which can be inferred by the low number of recordings of carnivores, compared to other studies (Santos et al. 2004, Kasper et al. 2007a, Marques et al. 2011). Because of the large living areas required by carnivores, a greater sampling effort is necessary to obtain more precise information of their distribution and abundance in Morro do Coco and other nearby hills and forest patches. In agreement with Becker \& Dalponte (1991), the tracks of P. yagouarondi are very similar to those of felines of the genus Leopardus, where the simple observation of the tracks for the distinction between the species can be hasty and prone to errors. However, the track still provides unique characteristics of the species, such as the impression of four rounded toes in a semicircle and well distanced from the pad (MorroRios et al. 2008). Such characteristics, along with the confirmation of the species by inhabitants, show consistent evidence of the presence of $P$. yagouarondi in the study area.

The inhabitants reported the occurrence of the only specialized insectivore encountered, Tamandua tetradactyla (Linnaeus, 1758), about five years ago. Kasper et al. (2007b) affirmed that the species is still relatively common in the Vale do Taquari, located in the central region of the state of Rio Grande do Sul, on the slope of the Serra Geral, despite the intense fragmentation of the landscape. However, because of the lack of consistent recordings of T. tetradactyla in the regions close to Morro do Coco, it is necessary to make a greater effort in the field to confirm the occurrence of the species.

With the use of only sand plots, the presence of a species of the genus Mazama was detected, which could not be determined to the species level only by analysis of the tracks. However, by the type of environment, state of conservation and distribution of cervid species, this was probably Mazama gouazoubira (G. Fischer, 1814), a welldistributed and well-adapted species, which can utilize these forests, fields and regenerating forests (Redford \& Einsenberg 1992, Silva 1994, Reis et al. 2006).

Among the 16 species found, seven (44\%) are threatened with extinction in Rio Grande do Sul, in the vulnerable category (Fontana et al. 2003). Leopardus pardalis is also considered threatened at the national level in the vulnerable category (Machado et al. 2008). Among the main threats to these species are habitat loss and fragmentation, hunting and being run over (Fontana et al. 2003).

The results of constancy analysis revealed a similar pattern with studies of disturbed areas (Sestren-Bastos 2006, Penter et al. 2008), where the most frequent species are those that have the capacity for adaptation to anthropogenic presence. The most constant species in the area were A. guariba, Cerdocyon thous (Linnaeus, 1766) and $D$. albiventris. Unlike $A$. guariba, a threatened species in Rio 
Grande do Sul, especially due to the fragmentation of the Atlantic Forest (Marques 2003), the last two species are usually found in altered environments (Fernandez \& Pires 2006, Magalhães 2007). The constancy of $A$. guariba in the study area can be explained by its conspicuous behavior and by the fact that monkey groups are currently restricted to the forest remnants of the region

Among the species listed, the presence of threatened species as well as widely distributed species and generalist and specialist species were recorded. Alouatta guariba, D. albiventris, C. thous, Hydrochoerus hydrochaeris (Linnaeus, 1766), Coendou spinosus (F. Cuvier, 1823) (= Sphiggurus villosus, according to Voss 2011), Dasypus novemcinctus Linnaeus, 1758, Procyon cancrivorous (G. Cuvier, 1798) and Myocastor coypus (Molina, 1782) are generally species more often found in anthropized places (Peres 1997, Ramos Junior et al. 2003, Dias \& Mikich 2006, Negrão \& ValladaresPádua 2006, Pedó et al. 2006, Kasper et al. 2007b, Araújo et al. 2008, Abreu Junior \& Köhler 2009). Lepus europaeus is considered an invasive species that occupies open areas and pastures, whose first recordings in Rio Grande do Sul date from the beginning of the XXth century (Instituto... 2012). However, the occurrence of more specialized carnivores such as P. yagouaroundi and L. pardalis, whose populations have declined in the state due to the loss of natural habitats (Indrusiak \& Eizirik, 2003), demonstrates the regional importance of the study area. The richness and composition of medium and large sized mammals found in Morro do Coco, with a predominance of generalist species and occasional recordings of rare and specialist species, suggest that the area is in a medium state of conservation. Despite the anthropic influence, Morro do Coco plays an important role in the conservation of medium and large sized mammals in the regional context, together with other forest remnants that comprise the landscape. However, by itself, it will not be able to contribute to the persistence of the mammalian fauna in the region, which requires studies in other remnants and evaluations on the landscape scale.

\section{Final Considerations}

Morro do Coco has been preserved by the Irmãos Lassalistas (a religious order) for more than 50 years. As a consequence, this area of native forest still maintains in part its original characteristics, serving as a refuge for various species of mammals and other faunal groups threatened with extinction in Rio Grande do Sul or which were already locally extinct in a large part of the metropolitan region of Porto Alegre. The marked species richness recorded for medium and large sized mammals, including various threatened species in the state of Rio Grande do Sul, as well as their considerable diversity of feeding habits (seven trophic categories), demonstrates the importance of the area for the conservation of the local mammalian fauna. Preserving Morro do Coco could contribute to conserving the community of medium and large sized mammals, and probably the ecological functions that they perform. Morro do Coco is situated in a zone prioritized for conservation of mammals in Greater Porto Alegre, since it consists of one of the last remnants where the phytophysionomies that originally occupied the edge of Guaiba Lake and granite hills of the region are represented and preserved.

\section{Acknowledgements}

We thank the team who helped us in field surveys and to Rosane Vera Marques for scientific contributions. We are also very grateful to Irmãos Lassalistas for the permission to carry out our field work in Morro do Coco. Dr. A. Leyva helped with the English translation and editing of the manuscript. Finally, we thank CNPq for financial support.

\section{References}

ABREU JUNIOR, E.F. \& KÖHLER, A. 2009. Mammalian fauna of medium and large sized in the RPPN of UNISC, RS, Brazil. Biota Neotrop. 9(4): http://www.biotaneotropica.org.br/v9n4/en/abstract?inventory+ bn02109042009 (último acesso em: 04/09/2010).

ANTONIO, M.G. (coord.). 1996. Plano de Manejo: Parque Estadual de Itapuã. Secretaria da Agricultura e Abastecimento, Departamento de Recursos Naturais Renovaveis, Porto Alegre.

ARAÚJO, R.M., SOUZA, M.B. \& MIRANDA, C.R. 2008. Densidade e tamanho populacional de mamíferos cinegéticos em duas Unidades de Conservação do estado do Rio de Janeiro, Brasil. Iheringia, Sér. Zool. 98(3):391-396. http://dx.doi.org/10.1590/S0073-47212008000300014

BACKES, A. 2000. Ecologia da Floresta do Morro do Coco, Viamão, RS. I - Flora e Vegetação. Pesquisas, Bot. 49:5-30.

BORGES P.A.L. \& TOMAS, W.M. 2008. Guia de rastros e outros vestígios de mamíferos do pantanal. Embrapa, Corumbá.

BECKER, M. \& DALPONTE, J.C. 1991. Rastros de mamíferos silvestres brasileiros: um guia de campo. Editora da Universidade de Brasília, Brasília.

BUTCHART, S.H.M., AKÇAKAYA, H.R., KENNEDY, E. \& HILTONTAYLOR, C. 2006. Biodiversity indicators based on trends in conservation status: strengths of the IUCN Red List Index. Conserv. Biol. 20:579-581. PMid:16903120.

CARVALHO JUNIOR, O. \& LUZ, N.C. 2008. Pegadas, série boas práticas. Editora da Universidade Federal do Pará, Belém.

CHIARELlO, A.G. 2000. Density and population size of mammals in remnants of Brazilian Atlantic Forest. Conserv. Biol. 14(6):1649-1657. http://dx.doi.org/10.1111/j.1523-1739.2000.99071.x

COLWELL, R.K. 2009. ESTIMATES: Statistical estimation of species richness and shared species from samples. EstimateS 8.2 User's Guide. http://viceroy.eeb.uconn.edu/EstimateS (último acesso em: 24/05/2012).

COSTA, J.P.O. 2001. Avaliação da reserva da biosfera da Mata Atlântica: cinco anos depois de seu reconhecimento pelo programa MaB-UNESCO. Cadernos RBMA (6):1-26.

DIAS, M. \& MIKICH, S.B. 2006. Levantamento e conservação da mastofauna em um remanescente de Floresta Ombrófila Mista, Paraná, Brasil. Bol. Pesq. Fl. 52:61-67.

EMMONS, H. \& FEER, F. 1997. Neotropical rainforest mammals, a field guide. University of Chicago Press, Chicago.

FERNANDEZ, F.A.S. \& PIRES, A.S. 2006. Perspectivas para a sobrevivência dos marsupiais brasileiros em fragmentos florestais: o que sabemos e o que ainda precisamos aprender? In Os marsupiais do Brasil: biologia, ecologia e evolução (N.C. Cáceres \& E.L.A. Monteiro-Filho, orgs.). Ed. UFSM, Campo Grande, p.191-201.

FONTANA, C.S., BENCKE, G.A. \& REIS, R.E. 2003. Livro vermelho da fauna ameaçada de extinção do Rio Grande do Sul. EdiPUCRS, Porto Alegre.

GOMES, D.F. 2006. Ecologia cognitiva e forrageio social em macacos-prego, Cebus nigritus (Goldfuss, 1809). Dissertação de mestrado, Pontifícia Universidade Católica do Rio Grande do Sul, Porto Alegre.

GONÇALVES, C.S. 2006. Distribuição e conservação do macaco-prego (Cebus nigritus Goldfuss, 1809) e documentação do conhecimento ecológico local na região do Parque Estadual de Itapeva e arredores, Rio Grande do Sul e Santa Catarina, Brasil. Dissertação de mestrado, Universidade Federal do Rio Grande do Sul, Porto Alegre.

HICKEL, H.T., ALBANO, M.T. F., PAVLICK, I.M.B. \& BETTIOL, D. 1998. A organização urbana. In Atlas Ambiental de Porto Alegre (R. Menegat, M.L. Porto, E.C. Carraro \& L. Bernardes, eds.). UFRGS, Porto Alegre, p.107-118.

INDRUSIAK, C. \& EIZIRIK, E. 2003. Carnívoros. In Livro vermelho da fauna ameaçada de extinção do Rio Grande do Sul (C.S. Fontana, G.A. Bencke \& R.E. Reis, orgs.). EDIPUCRS, Porto Alegre, p.507-533.

INSTITUTO HORUS. Base de dados nacional de espécies exóticas invasoras. I3N Brasil, Instituto Hórus de Desenvolvimento e Conservação Ambiental, Florianópolis. http://i3n.institutohorus.org.br (último acesso em 27/05/2012). 
KASPER, C.B., MAZIM, F.D., SOARES, J.B.G., OLIVEIRA, T.G. \& FABIÁN, M.E. 2007a. Composição e abundância relativa dos mamíferos de médio e grande porte no Parque estadual do Turvo, Rio Grande do Sul. Rev. Bras. Zool. 24(4):1087-1100. http://dx.doi.org/10.1590/S010181752007000400028

KASPER, C.B., FELDENS, M.J., MAZIM, F.D., SCHNEIDER, A., CADEMARTORI, C.V. \& GRILLO, H.C.Z. 2007b. Mamíferos do Vale do Taquari, região central do Rio Grande do Sul. Biociências 15(1):53-62.

KNOB, A. 1978. Levantamento fitossociológico da formação-mata do Morro do Coco, Viamão, RS, Brasil. Iheringia, Sér. Bot. 23:65-108.

LAGOS, A.R. \& MULLER, B.L.A. 2007. Hotspot brasileiro - Mata Atlântica. Saúde \& Amb. Rev. 2(2):35-45.

LEMA, T., VIEIRA, M. I. \&ARAÚJO, M. L. 1983. Fauna reptiliana do norte da grande Porto Alegre, Rio Grande do Sul, Brasil. Rev. Bras. Zool. 2(4):203227. http://dx.doi.org/10.1590/S0101-81751983000400002

MACHADO, A.M.B., DRUMMOND, G.M. \& PAGLIA, A.P. 2008. Livro vermelho da fauna brasileira ameaçada de extinção. MMA, Fundação Biodiversitas, Brasília.

MAGALHÃES, A.F.L. 2007. Fauna silvestre - quem são e onde vivem os animais na metrópole paulistana. In Mamíferos do município de São Paulo (A.F.L. Magalhães \& M.K. Vasconcellos, orgs.). Secretaria Municipal do Verde e do Meio Ambiente, São Paulo, p.284-336.

MARQUES, A.A.B. 2003. Primatas. In Livro vermelho da fauna ameaçada de extinção do Rio Grande do Sul (C.S. Fontana, G.A. Bencke \& R.E. Reis, orgs.). EDIPUCRS, Porto Alegre, p.499-506.

MARQUES, R.V., CADEMARTORI, C.V. \& PACHECO, S.M. 2011. Mastofauna no Planalto das Araucárias, Rio Grande do Sul, Brasil. Rev. Bras. Biocienc. 9(3): 278-288.

MENEGAT, R., PORTO, M.L., CARRARO, E.C. \& BERNARDES, L. 1998. Atlas Ambiental de Porto Alegre. UFRGS, Porto Alegre.

MORRO-RIOS, R.F., SILVA-PEREIRA, J.E., SILVA, P.W.E., MOURABRITTO, M. \& PATRPCÍNIO, D.N.M. 2008. Manual de Rastros da Fauna Paranaense. Instituto Ambiental do Paraná, Curitiba.

NEGRÃO, M.F.F. \& VALLADARES-PÁDUA, C. 2006. Registros de mamíferos de maior porte na Reserva Florestal do Morro Grande, São Paulo. Biota Neotrop. 6(2): http://www.biotaneotropica.org.br/v6n2/pt/ abstract?article+bn00506022006 (último acesso em 04/09/2011).

PAGLIA, A.P., FONSECA, G.A.B., RYLANDS, A.B., HERRMANN, G., AGUIAR, L.M.S., CHIARELLO, A.G., LEITE, Y.L.R., COSTA, L.P., SICILIANO, S., KIERULFF, M.C.M., MENDES, S.L., TAVARES, V.C., MITTERMEIER, R.A. \& PATTON, J.L. 2012. Lista anotada dos mamíferos do Brasil. 2. ed. Occas. Pap. Conserv. Biol. 6:1-76.

PARDINI, R., DITT, E.H., CULLEN JUNIOR , L., BASSI, C. \& RUDRAN, R. 2003. Levantamentos rápidos de mamíferos de médio a grande porte In Métodos de estudo em biologia da conservação e manejo da vida silvestre (L. Cullen Junior, R. Rudran \& C. Valladares-Pádua, eds.). UFPR, Curitiba, p.181-201.

PEDÓ, E., TOMAZZONI, A.C., HARTZ, S.M. \& CHRISTOFF, A.U. 2006 Diet of crab-eating fox, Cerdocyon thous (Linnaeus) (Carnivora, Canidae), in a suburban area of southern Brazil. Rev. Bras. Zool. 23(3):637-641. http://dx.doi.org/10.1590/S0101-81752006000300005

PENTER, C., PEDÓ, E., FABIÁN, M.E. \& HARTZ, S.M. 2008. Inventário rápido da fauna de mamíferos do Morro Santana, Porto Alegre, RS. Rev. Bras. Bioci. 6(1):117-125.

PERES, C.A. 1997. Effects of habitat quality and hunting pressure on arboreal folivore densities in neotropical forest: a case study of howler monkeys (Alouatta spp.). Folia Primatol. 68:199-222.
PRIMACK, R.B. \& RODRIGUES, E. 2001. Biologia da conservação. Ed. Rodrigues, Londrina.

RAMOS JUNIOR, V.A, PESSUTTI, C. \& CHIEREGATTO, C.A.F.S. 2003. Guia de identificação de canídeos brasileiros. JoyJoy Studio, Sorocaba.

REDFORD, K.H. \& EISENBERG, J.F. 1992. Mammals of the Neotropics: the Southern Cone: Chile, Argentina, Uruguay, Paraguay. The University of Chicago Press, Chicago.

REIS, N.R., PERACCHI, A.L., PEDRO, W.A. \& LIMA, I.P. 2006. Mamíferos do Brasil. Nélio R. Reis, Londrina.

ROCHA, E.D. \& DALPONTE, J.C. 2006. Composição e caracterização da fauna de mamíferos de médio e grande porte em uma pequena reserva de cerrado em Mato Grosso, Brasil. Rev. Árvore 30(4):669-678. http:// dx.doi.org/10.1590/S0100-67622006000400021

SANTOS, A.J. 2003. Estimativas de riqueza em espécies. In Métodos de estudos em Biologia da Conservação e manejo da vida silvestre (L. Cullen Junior, R. Rudran \& C. Valladares-Padua, orgs.). Ed. da UFPR, Fundação O Boticário de Proteção à Natureza, Curitiba, p.19-41.

SANTOS, M.F.M. 2001. Aspectos da ecologia e conservação dos mamíferos carnívoros no Parque Nacional dos Aparados da Serra (Cambará do Sul/ RS e Praia Grande/SC). Dissertação de Mestrado, Instituto de Biociências. Universidade Federal do Rio Grande do Sul, Porto Alegre.

SANTOS, M.F.B. \& CADEMARTORI, C.V. 2010. Estudo comparativo da avifauna em áreas verdes urbanas da região metropolitana de Porto Alegre, sul do Brasil. Biotemas 23(1):181-195. http://dx.doi.org/10.5007/21757925.2010v23n1p181

SANTOS, T.G, SPIES, M.R., KOPP, K., TREVISAN, R. \& CECHIN, S.Z. 2008. Mamíferos do campus da Universidade Federal de Santa Maria, Rio Grande do Sul, Brasil. Biota Neotrop. 8(1):125-131. http:// www.biotaneotropica.org.br/v8n1/pt/abstract?inventory+bn00508012008 (último acesso em: 04/10/2011).

SANTOS, M.F.M., PELLANDA, M., TOMAZZONI, A.C., HASENACK, H. \& HARTZ, S.M. 2004. Mamíferos carnívoros e sua relação com a diversidade de hábitats no Parque Nacional dos Aparados da Serra, sul do Brasil. Iheringia, Sér. Zool. 94(3):235-245. http://dx.doi.org/10.1590/ S0073-47212004000300003

SCHERER, A., SILVA-MARASCHIN, F. \& BAPTISTA, L.R.M. 2006. Padrões de interações mutualísticas entre espécies arbóreas e aves frugívoras em uma comunidade de Restinga no Parque Estadual de Itapuã, RS, Brasil. Acta bot. Bras. 21(1):203-2012. http://dx.doi.org/10.1590/ S0102-33062007000100019

SESTREN-BASTOS, M.C. 2006. Plano de Manejo Participativo do Parque Natural Morro do Osso. Secretaria Municipal do Meio Ambiente, Porto Alegre.

SILVA, F. 1994. Mamíferos silvestres: Rio Grande do Sul. 2. ed. Fundação Zoobotânica do Rio Grande do Sul, Porto Alegre.

SILVEIRA-NETO, S., NAKANO, O., BARBIN, D. \& NOVA, N.A.V. 1976. Manual de ecologia dos insetos. Editora Agronômica Ceres, São Paulo.

TABARELLI, M., PINTO, L.P., SILVA, J.M.C., HIROTA, M.M. \& BEDÊ, L.C. 2005. Desafio e oportunidades para conservação da biodiversidade na Mata Atlântica brasileira. Megadiversidade 1(1):132-138.

TONHASCA JUNIOR, A. 2005. Ecologia e história natural da Mata Atlântica. Interciência, Rio de Janeiro.

VOSS, R.S. 2011. Revisionary Notes on Neotropical Porcupines (Rodentia: Erethizontidae) 3. An Annotated Checklist of the Species of Coendou Lacépède, 1799. Am. Mus. Novit. (3720):1-36.

WITT, P.B.R. (coord.). 2008. Plano de Manejo: Unidade de Conservação Reserva Biológica do Lami José Lutzenberger. SMAM, Porto Alegre.

YENSEN, E. \& TARIFA, T. 2003. Galictis cuja. Mamm. Species (728):1-8. 